\title{
VİRÂNÎ BABA'DA YÜZ ÜZERİNE BİR İNCELEME
}

\author{
An Analysis of the Theme of Face in Virani Baba's Works
}

\section{Eine Untersuchung über die Rolle des Gesichts bei Virani Baba}

\author{
Mehmet TEMIZKAN*
}

DOI: http://dx.doi.org/10.22520/abked.2016.14.0005

"Musavverdir yüzünde cümle Kur'ân"

Bektaşî edebiyatının temel özelliklerinden biri, "insanı yüceltme"sidir. Diğger zümre edebiyatlarından ayrıldığı ana noktalar arasında, bu özelliği de vardır. İnsanın yüceltilmesi, büyük ölçüde "yüz" üzerinden yapılır. Bektaşilik ve Bektaşî edebiyatı, Seyyid Nesimîden itibaren Hurufiliğin etkisi altına girmiştir. Bu edebiyatın yedi büyük temsilcisinden biri olan Virânî Baba da Hurufî bir şairdir. Daha çok halk şiiri tarzında yazmış olması sebebiyle, Bektaşî şairler üzerindeki etkisi, bir divan şairi olan

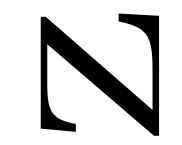
Seyyid Nesimî'den -muhtemelen- daha az değildir. Şiirlerinde Hz. Alî ve On İki İmam övgüsü önemli bir yer tutar. Ele aldığı önemli konular arasında yüz ve yüzün şahsında insan da bulunmaktadır: İnsan yüzünde dört kirpik, iki kaş ve bir zülf (saç) olmak üzere yedi hat bulunur. Evrenin yapısını oluşturan dört unsur vardır (hava, su, toprak, ateş). Yedi ile dört çarpılarak yirmi sekiz (28) -bazen de otuz iki (32)- sayısı elde edilir. Bu, Arap alfabesindeki harf sayısıdır ve bilindiği gibi Kur'ân da bu harflerle yazılmıştır. Bundan dolayı, insan yüzü Kur'ân'dır. Yüz, aynı zamanda Fâtiha'dır. Çünkü, yüzdeki hat sayısı ile bu suredeki ayet sayısı eşittir... Yüz, Fâtiha ve bütün Kurân olduğu için kutsaldır. Yüz, ayrıca Kâbe ve kıbledir... Bu özelliklerinden dolayı, secde yüze veya sahibi olan insana yapılmalıdır. Bunu yapmayanlar ise şeytandır... Bu çalışmada, Virânî̉deki yüzle ilgili inançlar ve Bektaşî edebiyatındaki etkileri ele alınmaktadır.

Anahtar Kelimeler: Virânî, Hurufilik, Yüz, Kur'ân, Fâtiha, İnsan.

* Doç. Dr., Ege Üniversitesi Türk Dünyası Araştırmaları Enstitüsü. 


\begin{abstract}
One of the basic characteristics of the Behtashi literature is "glorification of human being". This characteristic is one of themain differences between Bektashi and other group literatures. "Face" plays a large part in glorification of human being. Bektashism and Bektashi literature came under the influence of Hurufism with Seyyid Nesimi. Virani Baba, one of the seven major representatives of Bektashi literature, was also a Hurufi poet. Because of the fact that he wrote his poetry mostly in the style of folk poetry, his influence on Bektashi poets was probably as big as Seyyid Nesimi's influence. In his poetry, praising Ali and the Twelve Imams has an important place. The themes of face and human being are among significant themes he wrote about. On the human face there are seven lines: four eyelashes, two eyebrows and one hair. The structure of universe consists of four elements (air, water, earth, fire). Seven multiplied by four equals twenty-eight (28) - and sometimes thirty-two (32; Abjad numerals). This number presents the number of letters in Arabic alphabet and, as is known, Quran is written in the Arabic language. Also, face is al-Fatihah because the number of face lines is equal to the number of verses ("ayat") in this chapter ("surah"). Face is sacred because it is al-Fatihah and Quran; also, it is Kaaba and Qibla. For this reasons, "sajdah" must be done to a face or a human. Those who don't do that are devil... This paper analyzes the beliefs on face in Virani's works and the influences of these beliefs in the Bektashi literature.
\end{abstract}

Key Words: Virani, Hurufism, face, Quran, al-Fatihah, human. 


\section{ZUSAMMENFASSUNG}

"Die Verherrlichung des Menschen" bildet eine der Grundeingenschaften der Bektaschi-Literatur. Diese Eigenschaft zählt zu den Eckpunkten, durch die sich die Bektaschi-Literatur von den Literaturvorstellungen anderer Religionsgruppen unterscheidet. Die Verherrlichung des Menschen erfolgt überwiegend über die Hervorhebung des - menschlichen - "Gesichts". Das Bektaschitum und die BektaschiLiteratur sind seit Seyyid Nesimî unter den Einfluss des Hurufismus geraten. Virânî Baba, der zu den sieben großen Vertretern dieser Literatur zählt, war ebenfalls ein Hurufi-Dichter.

Da er vielmehr im Stil der Volksdichtung schrieb, beträgt sein Einfluss auf die Bektaschi-Dichter vermutlich nicht weniger als der Einfluss von Seyyid Nesimî, der ein Diwan-Dichter war. In seinen Gedichten spielt das Loben des Imam Ali und der Zwölf Imame eine wichtige Rolle. Zu den wichtigen Themen, die er in seiner Dichtung behandelte, zählen das Gesicht und der Mensch, der über die Symbolik des Gesichts beschrieben wird: Auf dem Gesicht des Menschen gibt es sieben Linien, die aus vier Wimpern und aus zwei Augenbrauen und aus einer Locke (Haar) bestehen. Der Kosmos besteht aus vier Elementen (Luft, Wasser, Erde, Feuer). Durch die Multiplikation der Zahl sieben mit der Zahl vier erhält man die Zahl achtundzwanzig (28) - manchmal auch zweiunddreißig (32). Dies entspricht der Anzahl der arabischen Buchstaben und wie bekannt ist, wurde auch der Koran mit diesen Buchstaben geschrieben. Daher wird das Gesicht des Menschen wie der Koran verstanden. Das Gesicht verkörpert zugleich auch die Eröffnungssure des Koran (Al-Fatiha). Denn die Anzahl der Linien auf dem Gesicht entspricht der Anzahl der Verse in dieser Koran-Sure... Das Gesicht ist heilig, weil es die Eröffnungssure (Al-Fatiha) und den ganzen Koran verkörpert. Außerdem verkörpert das Gesicht auch die Kaaba (Kâbe) und die muslimische Gebetsrichtung (k1ble).... Aufgrund dieser Eigenschaften sollte der Akt der Niederwerfung (secde) dem Gesicht und dem Menschen gelten, welcher der Besitzer des Gesichts ist. Diejenigen, die dies nicht praktizieren, sind der Teufel... Die vorliegende Arbeit befasst sich mit den Glaubensvorstellungen bei Virânî über das Gesicht und über deren Einfluss auf die Bektaschi-Literatur.

Schlüsselbegriffe: Virânî, Hurufîsmus, das Gesicht, der Koran, die Eröffnungssure des Koran (Al-Fatiha), der Mensch. 


\section{Niçin Virânî Baba ve Niçin Yüz?}

Virânî Baba, Bektaşî edebiyatının “yedi ulu”sundan biri ve inançları bakımından en farklı olanıdır. Turgut Koca'nın bildirdiğine göre, icazet almak üzere gittiği Demir Baba tarafindan Kur’ân'a uyması yönünde uyarılmıştır. (Koca, 1990: 192) Bu uyarı, şairin "fikrî kimliği”" ile yakından alakalıdır. Onun fikrî kimliğini açıklayabilecek en kısa ifade, kanaatimizce "aykırı ses" olmasıdır. Hurufilik felsefesine en az Seyyid Nesimî kadar bağlı olduğunu ve şiirlerini de bu felsefeyle ördüğünü söylemek, herhalde yanlış olmayacaktır. Ayrıca, Nusayrî olduğunu israrla vurgulayan ve Nusayrî olmakla gurur duyduğunu hissettiren -muhtemelen- tek Bektaşî şair de odur... Bektaşî edebiyatında, Hurufiliğin etkisinin bir sonucu olarak “yüz”ün vücudun diğer organlarından çok farklı bir konuma yerleştirildiği, daha açık bir ifadeyle yüceltildiği veya kutsallaştırıldığ1, hemen herkes tarafindan bilinen bir husustur. Ancak, bu yüceltme, daha çok “yuvarlak ve kalıp ifadeler"le yapılır. Çoğu da "niçin” sorusuna tatmin edici bir cevap vermekten uzaktır. Virânî Baba'da ise, söz konusu yüceltme hem üst seviyededir hem de "niçin" sorusunu sorma ihtiyacını bile hissettirmez. İşte bu iki özelliğiyle Virânî Baba'daki yüz tasavvurunun incelenmesinin, Bektaşî edebiyatının bu cephesinin daha iyi anlaşılmasına katkıda bulunacağı kanaatindeyiz.

Virânî Baba Hurufî olduğu ve şiirlerinin dokusunu da Hurufillik oluşturduğu için, "yüz" konusuna girmeden önce Hurufilliğin -ana hatlarıyla da olsa- bilinmesi gerekmektedir. Hurufiliğge göre, bir insanın yüzünde yedi hat vardır: İki kaş, dört kirpik ve bir de saç. Bu yedi hat dört unsur (hava, su, toprak, ateş) ile çarpıldığında, 28 sayısı elde edilir. Arap alfabesindeki ve dolayısıyla Kur'ân-1 Kerim'deki harf sayısı da 28'dir. (Gölpınarlı, 1992: 381) Dört unsurla çarpılmasının sebebini, yine Virânî Baba

"Mürekkebdir anasırdan bututu vech-i insânın" (Virânî, 1998: 244)

şeklindeki dizesiyle açıklamaktadır. Allah, bilgisini veya sırrını peygamberlerine harfler aracılı̆̆ıla bildirmiştir. Semavî kitaplardaki harf sayısı, kitabın indirildiği peygambere verilen ilahî bilginin de ölçüsüdür. En çok harf, Kur'ân-1 Kerim'de bulunmaktadır. Dolayısıyla, en fazla Tanrı bilgisi de Hz. Muhammed'e verilmiştir... Fâtiha suresinin adlarından biri, "Kitabın anası" anlamına gelen “Ümmü'l-kitâb”dır. Bu sure, Kur'ân-1 Kerim'in özüdür ve onda yedi ayet bulunmaktadır. Bu yedi ayet, insan yüzündeki yedi hatta karşllık gelir... Buradan hareketle, yüz ile Fâtiha arasında ilişki kurulur. Kur'ân-1 Kerim'in özü ve anası olan Fâtiha'daki bütün Tanrı bilgisi (veya sırrı), bu ilişki çerçevesinde insan yüzünde de bulunmaktadır. Yüzün yüceltilmesi veya kutsallaştırılmasının önemli sebeplerinden biri, budur. Diğer bir sebep de, Allah'ın 
insan bedeninde tecellî ettiği organlardan birinin yüz olduğu inancıdır. İnsan bedenini iki eşit parçaya böldüğüne inanılan ve iki kaşın arasından geçen hayalî çizginin ad1, "hatt-1 istevâ"dır. "Errahmânuale'l-arşi’s-tevâ..." (Rahmân (olan Allah) arşa istiva etti." ayetine dayanılarak, iki kaşın arası Tanrı'nın tecellî yeri olarak kabul edilir. Muhammed ve Alî isimlerinin insan yüzüne simetrik olarak yerleştirildiği Bektaşî tablolarında (illlüzyon), iki kaşın arasına da Allah ismi yazılır. Kaşın Allah’a yakınlık sembolü olması da, bu anlayışta etkilidir.

Yani yüz, hem Kur'ân-1 Kerim'in özü veya annesi olan Fâtiha suresindeki bütün Tanrı bilgisinin bulunduğu hem de Allah'ın tecellî ettiği organdır. Bu yüzden kutsaldır. Bektaşî edebiyatında ve -özellikle de- Virânî Baba'da da bu çerçevede ele alınıp değerlendirilmiştir.

\section{Virânî Baba'da Yüz}

Virânî Baba'nın hem Hurufî hem de Alevî-Bektaşî kimliği vardır. Bu kimliğinin bir sonucu olarak, "Hurufî-Alevî-Bektaşı̂" kimliğinin ürünü olan pek çok şiiri yanında, sadece "Hurufillik" kimliğinin ürünü olan mısraları da bulunmaktadır. Bunlar arasında yüzle ilgili olanları da vardır. Mesela, insan yüzünde Fadl veya Fazl isminin okunduğunu ya da yazılı olduğunu söylediği

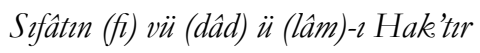

Ben an fą̣lı Hak Yeżdân okurmen (Virânî, 1998: 127)

şeklindeki mısraları, onun sadece Hurufî inancıyla ilgilidir. Hurufîlik etkisiyle aynı kanaati taşıyan -başta Hatayî olmak üzere- başka Alevî-Bektaşî şairler de vardır. (Atalay, 1991: 56) Virânî Baba'nın sadece Hurufî kimliğinin ürünü olan şiirleri, etkileriyle birlikte başlı başına bir makale konusu olabileceği için, bu çalışmada şairin söz konusu şiirlerine bu şekilde işaret edilmekle yetinilmiştir.

Virânî Baba'ya göre insan yüzü, her şeyden önce Allah’tan bir nişan taşımaktadır. -Bunun sebep veya sebepleri, ileride genişçe açılanacaktır.- Bundan dolayı, Hakk'1 görmek isteyen kişi âdemoğlunun yüzüne (suretine>suratına) bakmalıdır:

Ey Vîrânî kim dile görmeğe Hak

Sûreti âdemdedir nişânesi (Virânî, 1998: 99)

Virânî Baba, yüz için ayrıca "vech, suret, cemal, dîdâr, sıfat" isimlerini de kullanmaktadır. Birkaç yerde de "zülf, kaş, kirpik (ebrû)" demekte ve bunların 
bulunduğu yeri, yani yüzü işaret etmektedir. Şair, yukarıda açıklamaya çalıştığımız çerçeve dahilinde, en çok yüz ile Fâtiha arasında ilişki kurmaktadır. Yüzde yedi hattın, adı geçen surede de yedi ayetin bulunması, bu ilişkinin temelini oluşturmaktadır. Fâtiha'nın bir özelliği de "Besmele"yle ilgilidir. Besmele, bütün surelerin başında bulunur; ancak suredeki ayet sayısına dahil edilmez, Fâtiha'da ise birinci ayettir:

\section{Gör ne yaẓmıs hâme-i kudret cemâlin nakessina}

Evvelâ ol hatt-ı (bismillâh) etmiştir sudûr (Virânî, 1998: 251)

Fâtiha Kur'ân'ın anası veya özü olduğu için, onu oluşturan yedi ayette Kur'ân'ın bütün anlamı mevcuttur. Şair, Kur'ân yerine zaman zaman "Mushaf" ve "Furkan" isimlerini de kullanır; yüz veya cemal ile Mushaf arasında ilişki kurar. Kur'ân, son gelen kitap olması dolayısıyla, bünyesinde önceki kitapların bilgilerini de barındırmaktadır. Besmele Tefsiri'ndeki “Tanrı Te'âlâ Resûl'e hitâb etti. 'Ey Ahmet, gökten inen dört kitabın tamamını topladım, Fâtiha'nın içine koydum'..." (Duran, 2007: 31) Yani, Fâtiha'da bütün Kur'ân ve Kur'ân'da da bütün semavî kitaplar mevcuttur. Virânî Baba, bazı beyitlerinde bütün bu özellikleri bir araya getirerek hem inancını ortaya koyar hem de beyitlerine anlam derinliği ve zenginliği kazandırır:

\section{Yüzünde dilberâ Kurân okurmen}

Yedi âyet an her an okurmen (Virânî, 1998: 127)

Hem yine Ümmü'-kitâb'insûretin kıldı beyân

Doğdu andan dört kitâbın ma'nîsi uşbî-kusûr (Virânî, 1998: 251)

Sûret-i âdem değil mi mą̧har olan dört kitâb (Virânî, 1998: 196)

Dört kitâbın ma'nîsi seb'a'l-mesânîdir yü̃ün

Kim Zebûr-u Incil-ü Tevrât-u Furkân sen misin (Virânî, 1998: 225)

Yukarıda belirttiğimiz gibi, Hurufilikte Allah'ın kendi bilgisini peygamberlerine harfler aracılığıyla bildirdiği inancı vardır. Her harf, belli bir miktarda Tanrı bilgisini ihtiva eder. Fâtiha'yı oluşturan harflerde, bu surenin Kur'ân'ın annesi ve özü olmasından dolayı Kur'ân'daki bütün anlam gizlidir. Virânî Baba, bu noktadan hareketle, yüz ile Fâtiha arasında kurduğu ilişki yanında, yüz ile harf arasında da ilişki kurar. Fâtiha'da bulunan anlam, yüzde de vardır.

Yüzün harfinden açıldı cihâna her ne var mevcûd (Virânî, 1998: 11) 
şeklindeki mısra, işte bu anlam yumağının ifadesidir. Yüz, harf veya harflerdir ve var olan her bilgi, evrene yüz harfi ya da harfleri aracılığıyla açılmıştır (açıklanmıştır, bildirilmiştir).

Virânî Baba, bazen yüz yerine yedi hattı oluşturan "kaş, zülf ve kirpik"i kullanır; çünkü bunlar yüzde bulunmaktadır. Yüz ile Fâtiha arasında kurduğu ilişkiyi, bu ögelerle de kurar. Böylece, yüz-Fâtiha ilişkisinin temelini de açıklamış olur:

\section{Zülf-ü kaşın kirpiğindir (Fâtiha) Ümmü'l-kitâb}

Okurum her dem-be-dem Seb'a'l-mesân'ım gel beri (Virânî, 1998: 205)

Beyitte geçen "Seb'a'l-mesân”, "yedi inci" demektir ve yedi ayetten meydana gelen Fâtiha'nın diğer bir adıdır. Burada; zülf, kaş ve kirpiğin sayısının da yedi olduğunu hatırlamakta fayda vardır. Yukarıda açıklamaya çalıştığımız sebeplerden dolayı, Fâtiha Kur'ân demek olduğu için zülf, kaş ve kirpik, aynı zamanda Kur'ân'ın karş1lı̆̆1 olarak da düşünülür. Kısaca, yüz ve yüzde bulunan yedi hat ile Fâtiha ve Kur'ân arasında kurulan ilişkiyi bir bütün olarak değerlendirmekte fayda vardır. Aşağıdaki beyit, bu ilişki yumağının güzel bir açıklamasıdır:

\section{Kaşınla kirpiğin zülfün ben an dilde vird ettim}

Vücûdum hâfı̨ı cânâhatın Kur'ân edinmistir. (Virânî, 1998: 256)

Virânî Baba'nın şiirlerini okunduğumuzda, şairin yukarıda ortaya koymaya çalıştığımız inançlarının doğruluğunu ispat etme endişesi içinde olduğunu görürüz. İspat etmek için de Hurûfiliğin temel kabullerini kullanmaktadır. Yüz yerine kullanılan “sıfat"ın neden Kur'ân olduğunu açıklayan şu beyit, bu endişeyle söylenmiş olmalıdır:

\section{Sifatm bist- $\ddot{u}$ beşt $=(28)$ barf-i makdem}

bu barf ile gelir Kur'ân binâye (Virânî, 1998: 85)

Daha önce verdiğimiz örneklerin hiç birinde rakam telaffuz edilmemişti. Divân'da, bunun gibi rakamların kullanıldığı beyitler oldukça fazladır. Bu son örnekte geçen "sıfat", yüz anlamındadır; bu da yüzdeki yedi hattın yerine kullanılmıştır. Yedi hattın dört unsurla çarpılmasıyla 28 sayısı elde edilir. Yüzde, bu 28 sayısının karşıllı̆ı olan 28 harf bulunmaktadır. Bu 28 harf ise, bütün Kur'ân-1 Kerîm’i oluşturan işaretlerdir. Böylece, sıfat (yüz) ve yüzde bulunan 28 harfle vücuda getirilen Kur'ân arasında ilişki kurulmuş ya da yüzün Kur'ân olduğu ispat edilmiş olur. 
Yüz, bazen sayfaya; bazen de simetrik yapısından dolayı açık bir kitabın iki sayfasına benzetilir. Yüzde, benler ve ergenlik veya ayva tüyleri bulunur. "Ben" kelimesinin eski dildeki karşılığ1 "hâl” ve "ergenlik tüyü”nün karşıllı̆̆1 da "hat"tır. Ben, şekil özelliğiyle "nokta"dır; hat ise "yazı" demektir ve "harf”" anlamında da kullanılır. Harfler ve noktalar bir araya geldiğinde de yüz sayfasında bir ayet yazılmış olur. Virânî gibi, Bektaşî edebiyatının yedi büyügüünden biri olan Hatayî’nin şu beyiti, bu anlayışın ya da yorumun açı ifadesidir:

\section{Defter-i büsnin deşol harf-i hatt ü hâlin senin}

Satr-ı Bismillâhirrahmânirrahîm olmış durur (Memmedov, 1966: 178)

Bu ayet, Virânî Baba'ya göre de Besmele'dir. Bunun sebebi de, daha önce de geçtiği gibi, bütün surelerin başında bulunmasıdır:

Gör ne yaẓmıs hâme-i kudret cemâlin naksısına

Evvelâ ol hatt-ı (bismillâh) etmiştir sudûr (Virânî, 1998: 251)

Virânî Baba'nın yüz - edeb - Fâtiha arasında kurduğu ilişki de orijinaldir ve dikkati çekecek kadar anlam zenginliğine sahiptir. Şair, on bir beyitten oluşan bir şiirinde “edeb”i açıklamaya çalışmıştır: Kur'ân edeptir, Hak yolunun erkânı da edeptir. Edep, Hızır'ın elinden alınmasını tavsiye ettiği “ölümsüzlük suyu”dur. Kevser suyu da edeptir. Allah'ın arslanı olan Hz.Alî de edeptir. Gizli olan hazine (kenz-i mahfî) gibi, gizli hazinenin bulunduğu insan da edeptir... Bu şiirin birkaç beyiti şu şekildedir:

Beri gel tâlib-i Kur'ân edebdir

Kadd-ü vechi şehâ Furkan edebdir

Edeb câmın kap Hıær'in elinden

Hayat-u çeșme-i hayvân edebdir

Edebdir mîr-i meydânşîr-i Yezdân

Katardan çıkmagıl ey cân edebdir

Edebdir mesken eblinin durağ

Mekânm bil yürü insan edebdir

Edebdir ey Vîrânî sende mahfî

Olan genc-i Hudâ pinhân edebdir (Virânî, 1998:148) 
“Edeb”i -özet olarak- bu şekilde tanıtan Virânî Baba, başka bir şiirinde temiz bir nur olan edebin insan yüzünde bulunduğunu söyledikten sonra, edebin Fâtiha suresinin anlamı olduğunu da ilave eder. Fâtiha'nın namazın her rekatında okunması şarttır. Şair, bundan hareketle, Fâtihasız yani edepsiz namazın doğru (kılınmış) olmayacağı kanaatindedir. Aşağıdaki son beyitte geçen "edebsiz âdem...”, üzerinde düşünülmesi gereken bir ifadedir. Yukarıdaki anlam yanında "edepten yoksun insan" anlamına da alınabilir ve alınmalıdır. Böylece edep vurgulanmış olur. Burada, Hilmi Ziya Ülken’in Türk tasavvufuyla ilgili bir tespitini hatırlamak yararlı olacaktır. Ülken, İran tasavvufu ile Türk tasavvufunu karş1laştırırken şöyle demektedir: "İran tasavvufunun gayesi her şeyden evvel sanattır. $O$, mistik. halet-i rubiyeyi sanatkeârane bir dünya görüs̈̈̈nün vasitası olarak kullanır. Tasavvufun symbolisme'ine sirf bu maksatla müracaat etmistir. Halbuki Türk tasavvufunun gayesi bilakis her şeyden evvel ablak.tır... Türk tasavvufu bu sahasinda kendi gayesini alâkadar etmeyen ince ve sanatkârane bir symbolisme'den büsbütün styrlmıştır." (Ülken, 2016: 203-204) Virânî Baba’nın bu şiiri ve “edeb”le ilgili diğer şiirler, Ülken’in tespitine kaynaklık eden güzel örneklerdir... Edeb kelimesi, eski yazıyla elif, dâl ve bâ harfleriyle yazılır. Bu üç harfin ebced hesabıyla karşılığı da yedidir. Hatırlanacağı gibi, yedi hem Fâtiha'daki ayet hem de insan yüzündeki hat sayısıdır. Bu ortaklık sebebiyle edeb, hem Fâtiha hem de yüzdür:

\section{Edebdir vech-i insânda musavver \\ Aceb kudret aceb nûr-ı mutabher \\ Edebdir ma'nî-i (Seb'a'-mesânî) \\ Salat ansız, dürüst olmaz mukarrer \\ Edeb ebced hesâbryle yedidir \\ Kaşınla kirpiğin zülfün muanber \\ Edebsiz âdemin makbûul değildir \\ Namâzı vü niyą̂̃ işte defter (Virânî, 1998:139)}

Şairin Alevîlik ve Bektaşîlikte önemli bir yeri bulunan edep ile insan yüzü ve Fâtiha arasında kurduğu bu ilişki, yüzün yüceltilebileceği en uç seviyelerden biridir. Yukarıdan beri birkaç örneğini gördüğümüz anlam ilişkisi yumağı da, Virânî’nin inancına olan bağlılı̆̆ını ve inancındaki samimiyetini gösterdiği kadar, şairlik kudreti hakkında da ipuçları vermektedir. 
Virânî Baba, yine ebced hesabını kullanarak yüz ile Fâtiha arasındaki ilişkiyi derinleştirmeye ya da yüzün Fâtiha olduğunu ispat etmeye çalışır. Ancak, bunu açık açık söylemek yerine hissettirme yolunu seçerek yapar. Bir şeyi açık açık söylemek yerine ima yoluyla hissettirmek, okuyucuya yaşattığ1 "keşfetme zevki”"nin de katkısıyla daha etkili bir anlatım şeklidir. Bu anlatım şekli, eserin ve özellikle şiirin sanat değerini de yükseltir. Bundan dolayı, yazar veya şairin sanat gücünü yansıtması bakımından da önemlidir. Ayrıca, insan yüzünde ebced hesabının okunabileceğini söylemesi sebebiyle de anlamlı olan ve benzerleriyle çok az şairde karşılaşılabilen söz konusu beyit şudur:

Okursun ebcedin sirrn butût-ı vech-i âdemde

Beri gel eyle isbâtın nedir bu cîm ü dâlinden (Virânî, 1998:139)

Cim harfinin ebced hesabına göre sayı değeri 3, dâl harfinin ise 4'tür; toplandığında da 7 eder. 7 ise, hem Fâtiha'daki ayet hem de yüzdeki hat sayısıdır. İşte bu anlam ilişkileri, "vech-i âdem”de Fâtiha suresinin var olduğu inancını dile getirmeye imkan tanir.

Yüzdeki hat sayısı hesap edilirken, zülf tek kabul edilir. Ancak, zaman zaman "iki zülf" ifadesi de kullanılır. Bu ifadeyi kullanmanın çeşitli sebepleri vardır. İki zülf, saçın tam ortadan sağa ve sola ayrılması sonucu ortaya çıkar. Zülf sayısı ikiye çıkınca yüzdeki hat sayısı sekize ve dörtle çarpılması sonucunda da 32'ye çıkmış olur. (Gölpınarl1, 1992: 381) Bu sayıya, Arap alfabesine bu alfabede bulunmayan "p, ç, j, g” harflerinin eklenmesiyle ulaşıllır. 32 harf, Fazlullah-1 Hurufî tarafindan Farsça yazılan "Câvidan-nâme”de kullanılan harf sayısıdır; aynı zamanda Fazlullâh-1 Hurûfî'nin sahip olduğunu iddia ettiği ve Hurufîlerin sahip olduğuna inandığı bilginin de miktarıdır. (Hurûfilik, 1997: 598) Dolayısıyla, yüzde 28 harflik bilgiye ek olarak dört harflik, yani 32 harflik bilgi de bulunmaktadır... Kısaca, "iki zülf” ifadesinin kullanılma sebeplerinden biri, 32 sayısına ulaşmaktır:

Yüzünde ve sözünde ve özünde

Hemen si vü do =(32) beyânımdır mubakekak (Virânî, 1998:101)

Ediptir hatt-ı şâh-ı mubkemâtın

Ediptir si vü do =(32) hatt-ı vechinde (Virânî, 1998:133) 
Son beyitte geçen “muhkemât” kelimesinin “Kur'ân'1n kesin bir hüküm bildiren ayetleri" anlamına geldiği dikkate alındığında, şairin yüzdeki hatlarda 32 harfin bulunduğu inancına veya fikrine kesinlik kazandırmak istediği düşünülebilir.

"İki zülf" ifadesinin kullanılmasının bir diğer sebebi, hayalî "hatt-1 istevâ" çizgisi ve bu çizginin ifade ettiği anlamla ilgilidir. Saçın tam ortadan ikiye ayrılmasıyla oluşan çizgi, vücudu iki eşit parçaya böldüğü kabul edilen hayalî çizginin başıdır. Bu hayalî çizginin ad1, "hatt-1 istevâ"dır. Kur'ân-1 Kerîm'de "Allah'ın Arş'a istivâ ettiğì" bildirilmektedir. Buradan hareketle, söz konusu hayalî çizgi ve özellikle geçtiği "iki kaşın arası", Allah'ın tecellî ettiği mekan olarak kabul edilir. Zaten, cemâl "arş-

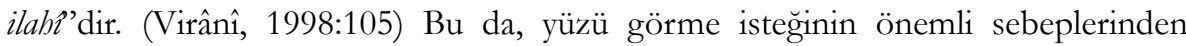
biridir... Kısaca yüz, Allah’ın tecellî ettiği organdır. Bu inancın açık bir ifadesi olan şu beyitteki “cânân”, Allah anlamındadır:

\section{Kimse maksud etmeyeydi görmeğe dîdârm \\ İki zülfün arasında râh-ı cânân olmasa (Virânî, 1998:185)}

Aşağıdaki beyitte anlam, adı anılmamakla birlikte yine bu hayalî çizgi üzerine kurulmuştur. Cemâl, yüz demektir. Yüzde bulunan sekiz hattın yarısı sağda, yarısı ise soldadır; ortadan da söz konusu çizgi geçmektedir. Yüzün bu yapısı, yüzün aya benzetilmesinden hareketle, Hz. peygamber'in parmağıyla ayı ikiye böldüğü 'şakku'lkamer" mucizesinin ortaya çıktığ1 yer olarak görülmesine imkan tanımıştır. Bu husustaki üç beyitten birinde tanık olduğumuz anlam zenginliği, bize, şairin kültür seviyesi yanında şairliği hakkında da ipuçları sunmaktadır (diğerleri için bk. Virânî, 1998:162;100):

\section{Cemâlin kirpiğin kaşınla zülfün \\ Șehâ sakeku'l-kamer ayân oluptur (Virânî, 1998:156)}

Bektaşî edebiyatının yedi ulu şairinden biri olan Virânî Baba, tahmin edilebileceği gibi, Hz. Alî’nin yüzünü de söz konusu eder ve onun yüzü ile Fâtiha arasında ilişki kurar. Temel endişesi Hz. Alî’yi yüceltmek olan şair, onun yüzünde Ümmü’l-kitâb’n manasını gördügünü söyler; bu özelliğiyle de "mazhar-1 Rahman" olarak nitelendirir. "Mazhar-1 Rahman", Allah'ın zuhur ettiği yer veya kişi demektir. Zuhur ise, tecellî anlamındadır:

\section{Biz, anm vechinde gördüke ma'nî-i Ümmü'-kitâb \\ Sûret-i Hak maz̧har-ı Rabmânmı̨dır Murtazâa (Virânî, 1998:187)}


Virânî'nin “E's-selâm ey sırr-ı Kur'âne's-selâm” (Virânî, 1998: 53) diye hitap ettiği Hz. Alî’nin adlarından veya vasıflarından biri, "Konuşan Kur'ân” anlamına gelen “Kur'ân-1 nâtık”tır. Virânî Baba, bu özelliğine bağlı olarak onun yüzünü Hakk'ın aşikâr olduğu yer olarak görmektedir. Aşağıdaki beyitte geçen “defter ü divân”dan kasıt, Kur'ân-1 Kerîm'dir:

\section{Hakekr gör niçin cemâlinden oluptur âşikâr}

Uș zuhûr-ı defter ü dîvân sensin yâ Alî (Virânî, 1998:199)

Virânî, az da olsa, diğer imamlarla Fâtiha veya Kur'ân arasında ilişki kurmaktadır. Mesela, bir şiirinde de yedinci imam Musa Kâzım'ın yüzünde yedi ayetin ve Kur'ân'ın okunmasını tavsiye etmektedir. (Virânî, 1998: 175) Ayrıca, yüzün veya yüzdeki hattın Yâsîn ve Tâhâ... sureleri olduğunu söylemektedir. Ancak, bu misralarında "niçin Yâsîn" ve "niçin Tâhâ" sorularına cevap olabilecek bir yorumda bulunmamaktadır. Bu yüzden, bu konuyla ilgili bir değerlendirmede bulunmaya imkan yoktur. Aynı şey, yüz ile "cennet-i adn” arasında kurduğu ilişki için de söz konusudur.

Bilindiği gibi, secde Allah'a yapılır. Secde, namazın bölümlerinden biridir ve secde yapılırken Kabe’ye yönelmek şarttır. Mescitlerdeki mihrab, Kabe’yi veya daha yaygın ismiyle "kıble"yi gösterir. Özellikle Hurufî şairler, mihrabı "duvar" olarak adlandırıp duvara karşı secde etmek yerine, yüze secde edilmesi gerektiğini sık sı1k dile getirirler. Bir yerde yüzün 'kıble-i ma'bûd” (Virânî, 1998: 11) olduğunu söyleyen Virânî Baba da bu şairlerden biridir. Ona göre yüze secde edilmesinin sebeplerinden biri, orada sultanın yani "Sübhan"ın gizli olmasıdır. Bundan da kasıt, yüzün "tecellîgâh-ı" ilahî olmasidir:

Ey perîvech-ü rubunda gizli sultan olmasa

Secde-gâh olmaz̧dı büsnün sende Sübhân olmasa (Virânî, 1998:185)

Yüze secde edilmesi gerektiğinin s1k sık dile getirilmesinin bir sebebi de, bunun Hz. Alî’nin bir tavsiyesi veya emri olmasıdır. Yüze secde etmeyenler ise pişman olacaklardir:

Yüzündür secdegâh-ı mü'minânm

Dedi şâh-ı velâyet hey imânm

Yü̃üne secde-i Hak etmeyenler

Bulur yarn nedâmet hey imânım (Virânî, 1998:106) 
“Âdem" kelimesi, hem özel hem de "insan" anlamında cins isimdir. Kur'ân-1 Kerîm'de, Allah'ın meleklere Âdem'e secde etmelerini emrettiği, meleklerin bu emre uyarak Âdem'e secde ettikleri... anlatılır. Şeytan, bu emre karşı çıkıp secde etmeye yanaşmamış ve bu hareketinden dolayı lanetlenmiştir. Şairler, "âdem” kelimesindeki cinasın da yardımıyla, Âdem'e secde etmekle ademe (insana) secde etmeyi birleştirebilir; insana veya yüze secde etmeyenleri de şeytan ya da mel'un olarak adlandirabilirler. Turabî'nin bu anlayışı ifade eden tipik bir beyiti vardır:

Ademi fark etmeyen, hayvan gelir hayvan gider

Ademe secde etmeyen, seytan gelir seytan gider (Turabî, 2006: 256)

“Zâhir” ve "bâtın”ın anlamının yüz üzerinde açıkça görülmesine rağmen Fakihin yüze niçin secde etmediğini anlayamadığını söyleyen (Virânî, 1998: 11) ve ifadesine biraz daha anlam zenginliği katan Virânî Baba ise, yüz için "Kabe" benzetmesine de yer verir ve yüze secde etmeyenleri şeytan olarak gördüklerini söyler:

\section{Çünkü re's-i vech-i âdem Kâbe-i tabkîk imis}

Secde-i ş̈̈̌r etmeyenler oldular şeytân bize (Virânî, 1998: 192)

"Kendi nefsini bilen Rabb’ini de bilir." anlamına gelen "Men arefe nefsehû fekad arefe Rabbehû" şeklinde bir kudsî hadis vardır. Bu hadis, dinî ve özellikle tasavvufî metinlerde çok sık kullanılır. Dolayısıyla "nefsini bilme" kavramı üzerinde çok durulur. Virânî Baba’ya göre, "men aref” sırrını bilmek, ancak insan yüzünün ifade ettiği manayı bilmekle mümkündür:

\section{Bilirsen âdemin vechin bilirsen (men aref) sirrn}

Görürsün Hak.k'ı tahkîkean olur müsküllerin âsân (Virânî, 1998: 246)

\section{Etkileri}

Seyyid Nesimî'den sonra, pek çok Alevî ve Bektaşî şairde on altıncı yüzyılın başından itibaren derin bir Hurufilik etkisiyle karşılaşmaktayız. -Fazla olmamakla birlikte, Bektaşî olmayan bazı şairlerde de aynı etkiyi görmekteyiz.- Bu etkiyi sadece Seyyid Nesimî ile açıklamak, kanaatimizce mümkün değildir. Seyyid Nesimî, bir divan şairidir. Geniş halk kitleleriyle onların inançlarına ve dünya görüşlerine tercüman olan, daha çok halk şiiri dairesine mensup olan şairlerin Nesimî'yi anlaması ve ondan etkilenmesi, çok da kolay değildir. Ayrıca, Nesimî’nin yaşadığı coğrafya, o dönemde Anadolu ve Balkanlar'daki Bektaşî şairleri etkilemeye pek de elverişli değildir. 
Nesimî’nin, çağdaşları üzerinde etkisinin bulunmaması da bu kanaatimizi destekler niteliktedir. Burada, Nesimînnin Bektaşî şairler üzerinde etkisinin hiç bulunmadığı̆nı değil, bu etkisinin büyük ölçüde Virânî Baba üzerinden söz konusu olduğunu söylemeye ve Virânî Baba'ya dikkat çekmek istiyoruz. Nitekim, Hilmi ziya Ülken'in "Ishak Hoca'nın kitabında zikeredilen esasl Hurufî metinleri sunlardır:" dedikten sonra verdiği eserler arasında Viran "Abdal Risâlesi "müptediler için” notuyla birlikte yer almakta, Nesimî Divanı ise anılmamaktadır. (Ülken, 2016: 322) Bu edebiyatın temel özelliklerinden biri, sade ve basit bir dille, millî vezin ve şekillerle yazılmış olmasıdır. Nesimî’nin dili ve kullandığı nazım şekilleri, ele aldığı konuların aksine, Bektaşî edebiyatının bu temel özelliğine biraz uzaktır. Bu bakımdan, şairlerdeki Hurufî etkide Virânî Baba'nın payının bulunduğunu ve bu payın hiç de küçük olmadığını söylemek mümkündür. Metinler de buna tanıklık etmektedir. Şemimî’nin

Bizdedir seb'ul-mesân â ars-ı Rahman bizdedir

Mą̧ar-ı Zül kibriyâyız. ulu Sübhan bizdedir (Koca, 1990: 362)

şeklindeki beyitinde, Virânî Baba'nın etkisi açıtır. Aynı şekilde, Turabî Sanî’ye ait olan

Kaş ü göz kirpik işte Fatiha Ümmü'l-kitap

Bilmeyenler Adem’i oldu bu gün Şeytân-ı Hak (Koca, 1990: 362)

şeklindeki beyitte de aynı şey söz konusudur. Muhyeddin Abdal'ın aşağıdaki dörtlüğü, Virânî’nin kullandığg kelimeleri kullanması bakımından daha da dikkate değer bir örnektir:

Mubyeddin'im Zubal'im

Ebcedim hatt $u$ hâlim

Harf-i noktay buldum

Vech-i Hûu cim ü dâlim (Koca, 1990: 142)

Alevî-Bektaşî şairlerde, bu örneklerin yüzlercesini bulmak mümkündür.

\section{Sonuç}

Virânî Baba, hem samimi bir Hurufî hem de kudretli bir şairdir. Zaten Bektaşî edebiyatının "yedi ulu”sundan biridir. Şair, Hurufî kimliğiyle, insan yüzünde iki kaş, dört kirpik ve bir de zülf olmak üzere yedi hattın bulunduğunu söyler. Bunu da dört (unsur) ile çarparak 28 sayısına ulaşır. Bu da Arap alfabesindeki harf sayısıdır. Kur'ân 
Arap alfabesiyle, yani 28 harfle yazılmıştır. Şair, bu noktadan hareketle yüzün Kur'ân olduğunu söylemiş ya da savunmuştur. Yine, yüzdeki hat sayısıyla Fâtiha suresindeki ayet sayısının eşit olması dolayısıyla da yüz ile bu sure arasında ilişki kurmuştur. Ayrıca, yüzün, bazen Allah'ın mekanı olarak bilinen “Arş” bazen de Kâbe veya kıble olduğunu belirtmiştir. Kısaca, yüzü yüceltmiş ve kutsallaştırmıştır. Bu özellikleri sebebiyle, yüze ve insana secde edilmesi gerektiği kanaatindedir. Bunu yapmayanlar ise şeytandır... Bütün bunlar, az veya çok neredeyse bütün Bektaşî şairlerde gördüğümüz şeylerdir. Virânî Baba, Bektaşî şairlerin yüz hakkındaki inançlarını biraz daha vurgulamış, biraz daha netleştirmiş ve açıklamaları ya da sebepleriyle birlikte ortaya koymuştur. Yüz ve yüzün şahsında insan hakkındaki kanaatini

\section{Cemâlinden haberdâr olmayanlar}

Sifât âdem tabiat hâr oluptur (Virânî, 1998: 157)

dizeleriyle çok veciz bir biçimde ortaya koyan Virânî Baba'nın yüzle ilgili inançlarının anlaşılması, Bektaşî edebiyatının yüz ve insan karşısındaki tavrının daha iyi anlaşılmasına yardımcı olacaktır. 
ALTINOK, Baki Yaşa (2006). haz. Turâbî Dîvânı, İstanbul: Horasan Yayınları.

ATALAY, Besim (1991). (Çev. Vedat Atila), Bektaşilik ve Edebiyatı, İstanbul: Ant Yayınları.

DURAN, Hamiye (2007). haz. Besmele Tefsiri, Ankara: Türkiye Diyanet Vakfı Yayınlari.

GÖLPINARLI, Abdülbâki (1992). Alevî-Bektaşî Nefesleri, İstanbul: İnkılâp Kitabevi.

(1997). "Hurûfîlik", MEB. İslâm Ansiklopedisi C. 5/1, Eskişehir: Milli Eğitim Bakanlığ1 Yay.

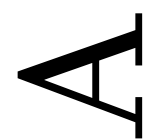

KOCA, Turgut (1990). Bektaşi Alevi Şair ve Nefesleri, İstanbul: İstanbul Maarif Kitaphanesi.

MEMMEDOV, Azizaga (1966). Şah İsmail Hatai-Eserleri, C. I, Bakı: Azerbaycan İlimler Akademiyası Neşriyatı.

ÜLKEN, Hilmi Ziya (2016).Türk Tefekkür Tarihi, İstanbul: Yapı Kredi Yayınlar1.

K VAKTİDOLU, Atalay (1998).der. Vîrânî Dîvânı ve Risalesi, İstanbul: Can Yayınları.

1
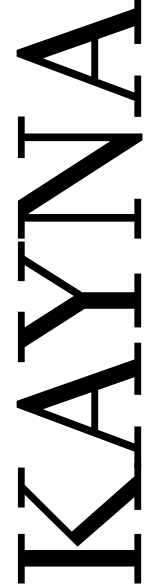